Correspondence to: Professor B K Nicholson

Chemistry Department

University of Waikato

Private Bag 3105

Hamilton

New Zealand

Email: b.nicholson@,waikato.ac.nz

Fax: 6478384219

\title{
Orthomercurated and cycloaurated derivatives of the iminophosphorane
}

$\mathrm{Ph}_{3} \mathbf{P}=$ NPh.*

Samuel D. J. Brown, William Henderson, Kelly J. Kilpin and Brian K Nicholson*

Department of Chemistry, University of Waikato, Private Bag 3105, Hamilton, New

Zealand.

* Dedicated with respect to Michael Lappert in recognition of his many contributions to chemistry, and in gratitude to him for his mentoring of BKN over the years. 


\section{Synopsis}

One of the $\mathrm{P}$-bonded phenyl rings of $\mathrm{Ph}_{3} \mathrm{P}=\mathrm{NPh}$ can be substituted at an ortho-carbon by an $\mathrm{HgCl}$ or by an $\mathrm{AuCl}_{2}$ group; only a weak $\mathrm{N} . . \mathrm{Hg}$ interaction is present for the mercury example, but the gold one is fully cyclometallated.

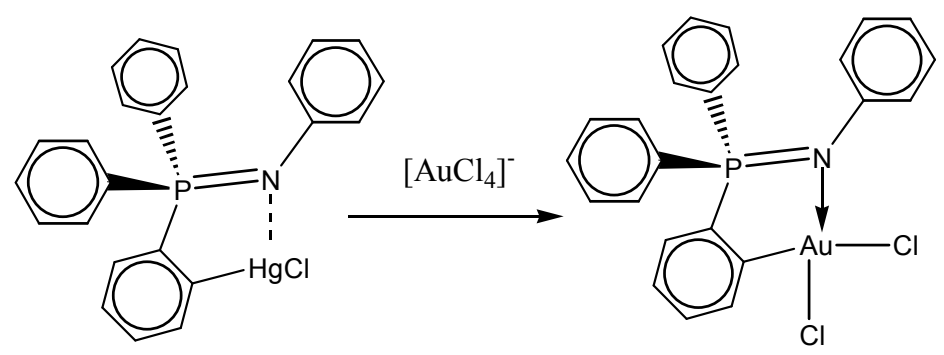

\section{Abstract.}

Ortho-lithiation of $\mathrm{Ph}_{3} \mathrm{P}=\mathrm{NPh}$ followed by reaction with $\mathrm{HgCl}_{2}$ gave good yields of $\left[\mathrm{Hg}\left\{\mathrm{C}_{6} \mathrm{H}_{4}\left(\mathrm{PPh}_{2}=\mathrm{NPh}\right)-2\right\} \mathrm{Cl}\right], \mathbf{3}$, which was characterised spectroscopically and by an Xray crystal structure determination. This is an isomer of the product of direct mercuration of $\mathrm{Ph}_{3} \mathrm{P}=\mathrm{NPh}$ which occurs on the N-bonded phenyl ring [Vicente et al, Organometallics, 22 (2003) 4248]. Transmetallation of $\mathbf{3}$ with $\left[\mathrm{AuCl}_{4}\right]^{-}$gave the corresponding cycloaurated complex $\left[\mathrm{Au}\left\{\kappa^{2}-C, N-\mathrm{C}_{6} \mathrm{H}_{4}\left(\mathrm{PPh}_{2}=\mathrm{NPh}\right)-2\right\} \mathrm{Cl}_{2}\right]$, with a five-membered metallocyclic ring incorporating four different elements. 


\section{Introduction.}

Iminophosphoranes, $\mathrm{R}_{3} \mathrm{P}=\mathrm{NR}$ ' are a readily accessible class of compound through the Staudinger reaction of $\mathrm{R}_{3} \mathrm{P}$ with $\mathrm{R}^{\prime} \mathrm{N}_{3}$, or from $\mathrm{R}_{3} \mathrm{PBr}_{2}$ and $\mathrm{R}^{\prime} \mathrm{NH}_{2}$ [1-3]. The electronic and steric properties can be tuned through appropriate choice of R and R'. Alper showed many years ago that the $\mathrm{Ph}_{3} \mathrm{P}=\mathrm{NR}$ ' examples underwent reaction with $\mathrm{Pd}(\mathrm{OAc})_{2}$ to give cyclopalladiated complexes 1 [4]. More recently, Vicente et al have prepared a more extensive range of cyclopalladiated examples, and examined their reactivity towards alkynes and isonitriles [5]. We have shown previously that direct cyclo-manganation and -rheniation of $\mathrm{Ph}_{3} \mathrm{P}=\mathrm{NPh}$ occurs readily to give 2 [6].

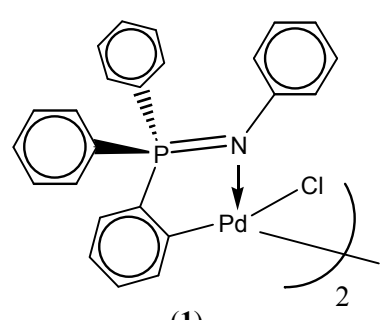

(1)

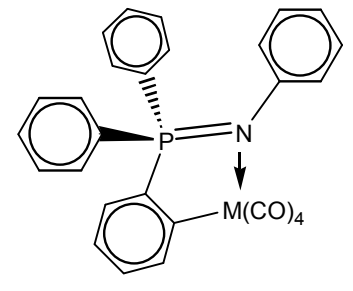

(2) $\mathrm{M}=\mathrm{Mn}$ or $\mathrm{Re}$

As far as we are aware these are the only cyclometallated derivatives of iminophosphoranes involving transition metals that have been prepared directly, though other examples of both transition- and main-group metal derivatives have been synthesised via ortho-lithiation of $\mathrm{Ph}_{3} \mathrm{P}=\mathrm{NR}$ ' followed by coupling with appropriate metal halides $[7,8]$.

We and others have been developing $\mathrm{Au}(\mathrm{III})$ chemistry based on cycloaurated C,Ndonor ligands which confer stability on this high oxidation state. So far most studies have concentrated on N,N-dimethylbenzylamine, and phenyl- or benzyl-pyridines as the substrate giving both five- and six-membered chelate rings [9-12]. The resulting square- 
planar complexes are also of interest for possible biological activity, since they are formally analogous to cis-Platin species, and pharmacological properties have been recognised for some cycloaurated $\mathrm{Au}(\mathrm{III})$ species [13]. For many of these compounds direct cycloauration with $\left[\mathrm{AuCl}_{4}\right]^{-}$is not viable, so transmetallation from the corresponding ortho-metallated mercury derivative is commonly employed [14].

We decided to explore the $\mathrm{Au}(\mathrm{III})$ chemistry of $\mathrm{Ph}_{3} \mathrm{P}=\mathrm{NPh}$, and this required the prior synthesis of the ortho-mercurated (on a P-bonded phenyl ring) intermediate. In this paper we report the syntheses and structures of the mercurated and aurated derivatives $\mathbf{3}$ and 4 respectively.

\section{Experimental Section}

\subsection{General}

Reactions were routinely carried out under a nitrogen atmosphere using Schlenk techniques and solvents that were distilled under nitrogen from appropriate drying agents before use. Electrospray mass spectra were recorded on a VG Platform II spectrometer, operated as detailed elsewhere [15]. Assignments were confirmed by simulation of the characteristic isotope patterns using the ISOTOPE program [16]. The peaks reported are the most intense in the isotopic envelope. NMR spectra were obtained on a Bruker AC300 instrument operating under standard conditions. IR spectra were recorded on a

Digilab Scimitar instrument as $\mathrm{KBr}$ disks. $\mathrm{Ph}_{3} \mathrm{P}=\mathrm{NPh}$ was prepared by a literature method [17] and $\left[\mathrm{Me}_{4} \mathrm{~N}\right]\left[\mathrm{AuCl}_{4}\right]$ from $\left[\mathrm{Me}_{4} \mathrm{~N}\right] \mathrm{Cl}$ and chloroauric acid..

\subsubsection{Preparation of (2-ClHgC $\left.\mathrm{H}_{4}\right) \mathrm{Ph}_{2} \mathrm{P}=\mathrm{NPh}$ (3).}


(a) $\mathrm{Ph}_{3} \mathrm{P}=\mathrm{NPh}(1.0 \mathrm{~g}, 2.83 \mathrm{mmol})$ was dissolved in dry, degassed ether $(30 \mathrm{~mL}) . \mathrm{A}$ solution of BuLi in hexane $\left(1.6 \mathrm{~mol} \mathrm{~L}{ }^{-1}, 2.0 \mathrm{~mL}, 3.2 \mathrm{mmol}\right)$ was added and the mixture was stirred for $3 \mathrm{~h}$. After cooling to $-84^{\circ} \mathrm{C}$ with an ethyl acetate slush bath, a solution of $\mathrm{HgCl}_{2}(0.84 \mathrm{~g}, 3.1 \mathrm{mmol})$ in thf $(10 \mathrm{~mL})$ was added. The solution was allowed to slowly warm to room temperature, and stirring was continued for $24 \mathrm{~h}$. The solvent was evaporated under vacuum and the residue extracted with $\mathrm{CH}_{2} \mathrm{Cl}_{2}(20 \mathrm{~mL})$. After filtration and evaporation the residue was redissolved in the minimum volume of $\mathrm{CH}_{2} \mathrm{Cl}_{2}$ and stored at $-20^{\circ} \mathrm{C}$ to give off-white crystals of $\left(2-\mathrm{ClHgC}_{6} \mathrm{H}_{4}\right) \mathrm{Ph}_{2} \mathrm{P}=\mathrm{NPh}(0.41 \mathrm{~g}, 25 \%)$. Found: C 49.62, H 3.61, N 2.31\%; $\mathrm{C}_{24} \mathrm{H}_{19} \mathrm{NPClHg}$ requires C 48.99, H 3.25, N 2.38\%; $\operatorname{NMR}\left(\mathrm{CDCl}_{3}\right):{ }^{1} \mathrm{H}: \quad \delta 6.71-6.75,6.93-6.96,7.02-7.07,7.28-7.33,7.44-7.5,7.68-7.73$ (all $\mathrm{m}, \mathrm{Ar}-\mathrm{H}) ;{ }^{13} \mathrm{C}: \delta 119.4(\mathrm{~s}), 124.0\left(\mathrm{~d}, J_{\mathrm{PC}}=14.7 \mathrm{~Hz}\right), 128.3\left(\mathrm{~d}, J_{\mathrm{PC}}=14.6 \mathrm{~Hz}\right), 128.0(\mathrm{~s})$, $129.2(\mathrm{~s}), 129.4(\mathrm{~s}), 130.0(\mathrm{~s}), 130.8(\mathrm{~s}), 131.8\left(\mathrm{~d}, J_{\mathrm{PC}}=3.1 \mathrm{~Hz}\right), 132.6\left(\mathrm{~d}, J_{\mathrm{PC}}=2.9 \mathrm{~Hz}\right)$, $133.3(\mathrm{~s}), 133.3$ (s), 133.4 (s), 133.5 (s), 135.8 (s), 137.1 (s), 138.5 (d, $\left.J_{\mathrm{PC}}=12.4 \mathrm{~Hz}\right), 149.0$ (s); ${ }^{31} \mathrm{P} \delta 8.6,{ }^{3} J\left({ }^{199} \mathrm{Hg}-\mathrm{P}\right) 326 \mathrm{~Hz} . \mathrm{ESMS}(\mathrm{MeOH}) \mathrm{m} / \mathrm{z} 612[\mathrm{M}+\mathrm{Na}]^{+}, 590[\mathrm{M}+\mathrm{H}]^{+} . \mathrm{IR}$ $\mathrm{v}(\mathrm{P}=\mathrm{N}) 1304 \mathrm{~cm}^{-1}$.

(b) $\mathrm{A} \mathrm{N}_{2}$-flushed Schlenk flask was charged with $\mathrm{PhBr}(0.30 \mathrm{~mL}, 0.44 \mathrm{~g}, 2.8 \mathrm{mmol})$ and $\mathrm{Et}_{2} \mathrm{O}(10 \mathrm{~mL})$. A solution of BuLi (2 mL of $1.6 \mathrm{~mol} \mathrm{~L}^{-1}$ solution, $\left.3.2 \mathrm{mmol}\right)$ was added and the mixture stirred for $15 \mathrm{~min}$. Solid $\mathrm{Ph}_{3} \mathrm{P}=\mathrm{NPh}(1.0 \mathrm{~g}, 2.8 \mathrm{mmol})$ was added in one portion. The solution turned orange as the solid dissolved and then a yellow precipitate formed. After stirring for $1.5 \mathrm{~h}, \mathrm{HgCl}_{2}(0.82 \mathrm{~g}, 3.0 \mathrm{mmol})$ was added in one portion. The mixture became colourless, with a white precipitate forming. After $1 \mathrm{~h}$ the solvent was evaporated and the residue extracted with $\mathrm{CH}_{2} \mathrm{Cl}_{2}(2 \times 10 \mathrm{~mL})$. The filtered extracts were 
treated with $\mathrm{Et}_{2} \mathrm{O}(20 \mathrm{~mL})$ and crystals of the product formed after storing at $-20^{\circ} \mathrm{C}$ overnight (1.01 g, 60\%).

\subsubsection{Preparation of $\left(2-\mathrm{Cl}_{2} \mathrm{Au} \mathrm{C}_{6} \mathrm{H}_{4}\right) \mathrm{Ph}_{2} \mathrm{P}=\mathrm{NPh}$ (4).}

$\left(2-\mathrm{ClHgC}_{6} \mathrm{H}_{4}\right) \mathrm{Ph}_{2} \mathrm{P}=\mathrm{NPh}(0.35 \mathrm{~g}, 0.59 \mathrm{mmol})$ was dissolved in degassed acetonitrile (30 $\mathrm{mL}) .\left[\mathrm{Me}_{4} \mathrm{~N}\right]\left[\mathrm{AuCl}_{4}\right](0.24 \mathrm{~g}, 0.59 \mathrm{mmol})$ and $\left[\mathrm{Me}_{4} \mathrm{~N}\right] \mathrm{Cl}(0.06 \mathrm{~g}, 0.55 \mathrm{mmol})$ were added and the flask was wrapped in foil to exclude light. The mixture was stirred for $2 \mathrm{~d}$. The solvent was evaporated under vacuum and the residue was dissolved in $\mathrm{CH}_{2} \mathrm{Cl}_{2}$. Filtration removed the white by-product $\left[\mathrm{Me}_{4} \mathrm{~N}\right]\left[\mathrm{HgCl}_{3}\right]$. The filtrate was slowly evaporated until the first sign of crystallisation and was stored at $-20^{\circ} \mathrm{C}$ overnight to give yellow crystals of $\left.\left(2-\mathrm{Cl}_{2} \mathrm{AuC}_{6} \mathrm{H}_{4}\right) \mathrm{Ph}_{2} \mathrm{P}=\mathrm{NPh}\right)(0.217 \mathrm{~g}, 59 \%)$. Found: C 43.23, H 2.95, N 2.10\%; $\mathrm{C}_{24} \mathrm{H}_{19} \mathrm{NPCl}_{2} \mathrm{Au} . \mathrm{CH}_{2} \mathrm{Cl}_{2}$ requires C 42.68, H 3.01, N 1.99\%; NMR $\left(\mathrm{CDCl}_{3}\right):{ }^{1} \mathrm{H}: \quad \delta \quad 5.30$ (s, $\mathrm{CH}_{2} \mathrm{Cl}_{2}$ ), 6.97-7.13, 7.30-7.36, 7.41-7.52, 7.54-7.58, 7.68-7.77, 8.40-8.42 (all m, Ar$\mathrm{H}) ;{ }^{13} \mathrm{C}: \delta 124.1(\mathrm{~s}), 125.3(\mathrm{~s}), 126.2\left(\mathrm{~d}, \mathrm{~J}_{\mathrm{PC}}=2.0 \mathrm{~Hz}\right), 128.3(\mathrm{~s}), 128.4\left(\mathrm{~d}, \mathrm{~J}_{\mathrm{PC}}=1.4 \mathrm{~Hz}\right)$, 128.5 (s), 129.5 (s), 129.6 (s), 129.7 (d, J $\mathrm{PC}=18 \mathrm{~Hz}), 129.8$ (s), 133.4 (s), 133.5 (s), 133.6 (s), $133.8\left(\mathrm{~d}, \mathrm{~J}_{\mathrm{PC}}=3 \mathrm{~Hz}\right), 134.5\left(\mathrm{~d}, \mathrm{~J}_{\mathrm{PC}}=2.8 \mathrm{~Hz}\right), 142.7(\mathrm{~s}), 149.5(\mathrm{~s}), 149.7(\mathrm{~s}) ;{ }^{31} \mathrm{P} \delta 65.6$. ESMS $(\mathrm{MeOH}) \mathrm{m} / \mathrm{z} 616[\mathrm{M}-\mathrm{Cl}+\mathrm{MeOH}]^{+}, 584[\mathrm{M}-\mathrm{Cl}]^{+} . \mathrm{IR} v(\mathrm{P}=\mathrm{N}) 1244 \mathrm{~cm}^{-1}$.

\section{$2.3 X$-ray crystallography}

X-ray intensity data were collected on a Siemens SMART CCD diffractometer using standard procedures and software. Empirical absorption corrections were applied (SADABS [18]). Structures were solved by direct methods and developed and refined on $\mathrm{F}^{2}$ using the SHELX programmes [19] operating under WinGX [20]. Hydrogen atoms were included in calculated positions.

\subsubsection{Structure of of $\left(2-\mathrm{ClHgC}_{6} \mathrm{H}_{4}\right) P h_{2} P=N P h$ (3).}


Colourless block crystals of $\mathbf{3}$ were obtained from $\mathrm{CH}_{2} \mathrm{Cl}_{2}$.

Crystal data: $\mathrm{C}_{24} \mathrm{H}_{19} \mathrm{NPClHg}, \mathrm{M}=588.41$, monoclinic, space group $\mathrm{P} 2{ }_{1} / \mathrm{c}, \mathrm{a}=$ 10.2061(1), $b=12.8252(2), c=16.1800(1) \AA, \beta=104.713(1)^{\circ}, \mathrm{U} 2048.44(4) \AA^{3}, \mathrm{~T} 83 \mathrm{~K}$, $\mathrm{Z}=4, \mathrm{D}_{\text {calc }}=1.908 \mathrm{~g} \mathrm{~cm}^{-3}, \mu\left(\mathrm{Mo}-\mathrm{K}_{\alpha}\right)=7.732 \mathrm{~mm}^{-1}, \mathrm{~F}(000) 1128 ; 12073$ reflections collected with $2^{\circ}<\theta<26^{\circ}, 4175$ unique $\left(\mathrm{R}_{\text {int }} 0.0162\right)$ used after correction for absorption $\left(\mathrm{T}_{\max , \min } 0.307,0.157\right)$. Crystal dimensions $0.38 \times 0.24 \times 0.20 \mathrm{~mm}^{3}$. Refinement on $\mathrm{F}^{2}$ gave $R_{1} 0.0177[\mathrm{I}>2 \sigma(\mathrm{I})]$ and $\mathrm{wR}_{2} 0.0427$ (all data), GoF 1.164. The structure of $\mathbf{3}$ is illustrated in Figure 1, with selected bond parameters summarised in Table 1 2.3.2 Structure of of $\left(2-\mathrm{Cl}_{2} \mathrm{AuC}_{6} \mathrm{H}_{4}\right) \mathrm{Ph}_{2} \mathrm{P}=\mathrm{NPh} . \mathrm{CH}_{2} \mathrm{Cl}_{2}\left(4 . \mathrm{CH}_{2} \mathrm{Cl}_{2}\right)$.

Yellow crystals of $\mathbf{4}$ as the mono solvate were obtained from $\mathrm{CH}_{2} \mathrm{Cl}_{2}$.

Crystal data: $\mathrm{C}_{24} \mathrm{H}_{19} \mathrm{NPCl}_{2} \mathrm{Au} . \mathrm{CH}_{2} \mathrm{Cl}_{2}, \mathrm{M}=705.16$, orthorhombic, space group $\mathrm{P} 2_{1} 2_{1} 2_{1}$, a $=9.3827(4), \mathrm{b}=13.5335(6), \mathrm{c}=19.5831(9) \AA, \mathrm{U} 2486.7(2) \AA^{3}, \mathrm{~T} 83 \mathrm{~K}, \mathrm{Z}=4, \mathrm{D}_{\text {calc }}=$ $1.884 \mathrm{~g} \mathrm{~cm}^{-3}, \mu\left(\mathrm{Mo}-\mathrm{K}_{\alpha}\right)=6.425 \mathrm{~mm}^{-1}, \mathrm{~F}(000) 1360 ; 15096$ reflections collected with $2^{\circ}$ $<\theta<26^{\circ}, 5065$ unique $\left(\mathrm{R}_{\text {int }} 0.0211\right)$ used after correction for absorption $\left(\mathrm{T}_{\max , \min } 0.360\right.$, 0.286). Crystal dimensions $0.26 \times 0.24 \times 0.20 \mathrm{~mm}^{3}$. Refinement on $\mathrm{F}^{2}$ gave $\mathrm{R}_{1} 0.0220$ [I $>2 \sigma(\mathrm{I})]$ and $\mathrm{wR}_{2} 0.0535$ (all data), GoF 1.004 , Flack x parameter $0.010(5)$. The structure of 4 is illustrated in Figure 2, with selected bond parameters summarised in Table 1

2.4 Biological activity.

An assay of the gold compound 3 against a P388 Murine Leukemia cell line was performed by the Marine Chemistry Group, University of Canterbury, New Zealand. Details are published elsewhere [12]. This gave an $\mathrm{IC}_{50}$ of $7546 \mathrm{ng} \mathrm{ml}^{-1}$ or $10.7 \mu \mathrm{M}$. 


\section{Results and discussion}

\subsection{Synthesis and properties of 3.}

Since it is known that direct mercuration of $\mathrm{Ph}_{3} \mathrm{P}=\mathrm{NPh}$ occurs at the N-bonded phenyl ring [5], we have developed a synthesis of the derivative of $\mathrm{Ph}_{3} \mathrm{P}=\mathrm{NPh}$ with mercury on the P-bonded phenyl ring via an intermediate lithiated species [c.f. 7,8], as in Scheme 1.

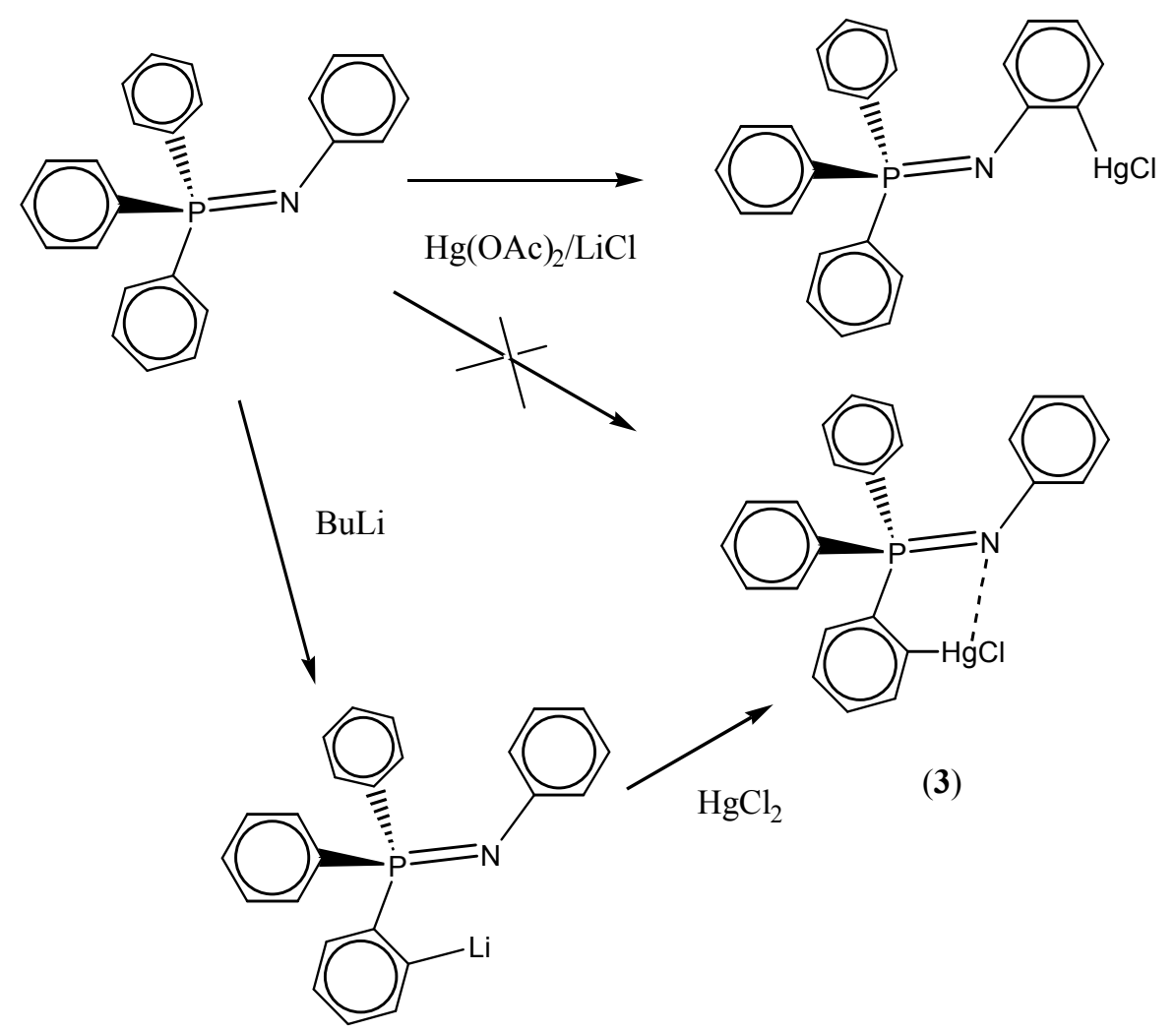

Scheme 1

This provided moderate yields of $\mathbf{3}$, with the mercury attached to one of the P-bonded phenyl groups. This is the isomer of the compound produced from a direct mercuration reaction, where attachment is on the N-bonded phenyl group [5]. Initially lithiation was carried out with BuLi. Examination of the crude reaction mixture by electrospray mass 
spectrometry showed the presence of several by-products, including $\mathrm{Bu}(2-$

$\left.\mathrm{ClHgC}_{6} \mathrm{H}_{4}\right) \mathrm{PhP}=\mathrm{NPh}$. An early paper on the lithiation of $\mathrm{Ph}_{3} \mathrm{P}=\mathrm{NPh}$ showed that exchange of groups on phosphorus occurred readily with $\mathrm{BuLi}$ [21]. Hence the method was modified by producing $\mathrm{PhLi}$ in situ (from $\mathrm{Li} / \mathrm{Br}$ exchange between $\mathrm{PhBr}$ and $\mathrm{BuLi}$ ) before adding $\mathrm{Ph}_{3} \mathrm{P}=\mathrm{NPh}$. This led to much improved yields of $\mathbf{3}$.

The new compound was characterised by elemental analysis and ${ }^{1} \mathrm{H},{ }^{13} \mathrm{C}$ and ${ }^{31} \mathrm{P}$ NMR spectroscopy. The ${ }^{31} \mathrm{P}$ signal for 3 comes at $\delta 8.6 \mathrm{ppm}$, the relatively small shift from that at $3.6 \mathrm{ppm}$ for the free ligand suggesting a simple metallation rather than a cyclometallated species involving coordination of the $\mathrm{N}$ atom to $\mathrm{Hg}$ as well [22]. The appearance of ${ }^{199} \mathrm{Hg}$ satellites on the $\mathrm{P}$ signal strongly supported metallation at a Pbonded, rather than an N-bonded, phenyl ring. To confirm this a single-crystal X-ray structure determination was carried out. The molecule is shown in Figure 1. It confirms the position of the $-\mathrm{HgCl}$ group at an ortho site on a P-bonded phenyl ring. The geometry at $\mathrm{Hg}$ shows a small deviation from linearity $\left[\mathrm{C}-\mathrm{Hg}-\mathrm{Cl} 170.16(8)^{\circ}\right]$ and a smaller $\mathrm{P}(1)$ $\mathrm{C}(11)-\mathrm{C}(12)$ angle of $106.8(1)^{\circ}$ than the other two $\mathrm{P}(1)-\mathrm{C}(11)-\mathrm{C}$ angles [av. 115.9(1) ${ }^{\circ}$ ]. These accommodate a weak $\mathrm{N}(1) \ldots \mathrm{Hg}(1)$ interaction $\{2.637(2) \AA$ c.f. a normal $\mathrm{Hg}$ $\mathrm{N}$ (imine) bond of ca $2.25 \AA[23]\}$ which is obviously significant but is not sufficient to regard $\mathbf{3}$ as a true cyclometallated derivative. However it is sufficient to constrain an overall conformation where the pseudo-cyclic ring is planar to within $\pm 0.13 \AA$. The Nbonded phenyl ring is twisted $8^{\circ}$ from this plane, compared with the free ligand where the corresponding twist is $11^{\circ}$ (c.f. the true cyclometallated complexes discussed below). Only small differences are seen for the rest of the ligand when compared to $\mathrm{Ph}_{3} \mathrm{P}=\mathrm{NPh}$ itself [24]. 
The electrospray mass spectrum of $\mathbf{3}$ in methanol gave a strong peak at $m / z 590$ which corresponds to the $[\mathrm{M}+\mathrm{H}]^{+}$ion, which suggests that the $\mathrm{N}$ atom is available for chemical ionisation by protonation, and not obstructed by the weak $\mathrm{Hg} \ldots \mathrm{N}$ interaction.

\subsection{Synthesis and properties of 4.}

Compound 4 is conveniently prepared by a simple transmetallation reaction between the mercury compound $\mathbf{3}$ and $\left[\mathrm{AuCl}_{4}\right]^{-}$, Scheme 2, following the precedents established for other potential C,N bonding ligands [14].

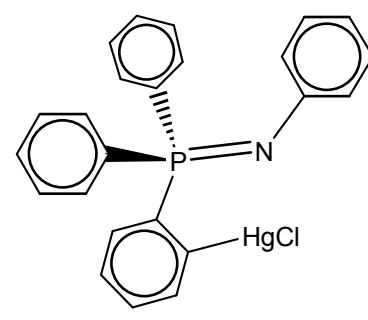

(3)
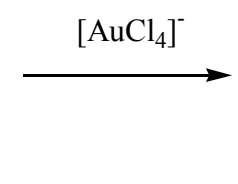

The electrospray mass spectrum in methanol showed major peaks at $\mathrm{m} / \mathrm{z} 584$ and 616 which can be assigned to $[\mathrm{M}-\mathrm{Cl}]^{+}$and $[\mathrm{M}-\mathrm{Cl}+\mathrm{MeOH}]^{+}$respectively. In this case there is no $[\mathrm{M}+\mathrm{H}]^{+}$signal at $\mathrm{m} / \mathrm{z} 619$, indicating that the $\mathrm{N}$ atom is no longer available for protonation. The ${ }^{31} \mathrm{P}$ NMR signal at $\delta 65 \mathrm{ppm}$ shows a large shift from the free ligand (and from the value in $\mathbf{3}$ ) consistent with incorporation into a five-membered metallocyclic ring [22]. One of the advantages of having a phosphorus atom in the ligand is that the large changes in ${ }^{31} \mathrm{P}$ chemical shifts from non-cyclised to cyclised forms is potentially useful for examining the reactivity of cycloaurated systems - in the (damp) $\mathrm{AuCl}_{2}$ complexes some ligands displaced the $\mathrm{N}$-donor atom; corresponding opening of the metallocyclic ring for $\mathbf{4}$ could be readily screened using ${ }^{31} \mathrm{P}$ NMR. Full cyclometallation was confirmed by the crystal structure determination which revealed the 
molecule shown in Fig 2. This has a square planar (to $\pm 0.05 \AA$ ) $\mathrm{Au}$ (III) centre, attached to two $\mathrm{Cl}$ ligands, and to the $\mathrm{N}$ and an ortho- $\mathrm{C}$ atom of the $\mathrm{Ph}_{3} \mathrm{P}=\mathrm{NPh}$ ligand. This generates a five-membered metallocyclic ring which is significantly puckered, with deviations of $+0.24[\mathrm{~N}(1)]$ and $-0.20 \AA[\mathrm{P}(1)]$ from the least-squares plane. The metallocyclic plane and the Au coordination plane are twisted to give an angle of $14^{\circ}$ between them. In the related cyclomanganated derivative $\mathbf{2}$ the metallocyclic ring was essentially planar, so there is clearly flexibility in these rings arising from the incorporation of the $s p^{3} \mathrm{P}$ atom. The $\mathrm{Au}-\mathrm{N}(1)$ and $\mathrm{Au}-\mathrm{C}(12)$ distances are the same length $(2.035(4) \AA)$ and give a $\mathrm{N}(1)-\mathrm{Au}(1)-\mathrm{C}(12)$ angle of $84.9(2)^{\circ}$, very similar to that in the orthomanganated example [6], suggesting the 'bite' is relatively rigid. In this example the $\mathrm{N}$-bonded phenyl ring is twisted to $54^{\circ}$ from the metallocycle plane. The strong bonding of the $\mathrm{N}$ atom to $\mathrm{Au}$ has lengthened both the $\mathrm{P}=\mathrm{N}$ and the $\mathrm{N}(1)-\mathrm{C}(41)$ bonds compared to the free ligand [25], and to the mercurated example 3. Finally, the higher trans-influence of $\mathrm{C} v s \mathrm{~N}$ is reflected in the longer $\mathrm{Au}-\mathrm{Cl}(1)$ distance compared to $\mathrm{Au}-\mathrm{Cl}(2)$.

The biological activity of the gold(III) compound $\mathbf{3}$ was screened against a P388 Murine Leukaemia cell line, and showed an $\mathrm{IC}_{50}$ value of $7546 \mathrm{ng} \mathrm{ml}^{-1}(11 \mu \mathrm{M})$. This represents significant activity, but is less than for other cyclometallated species [12]. Compound 3 was poorly soluble in biologically relevant solvents so derivatives modified to improve hydrophilicity can be expected to show higher activity.

\section{Conclusions.}

We have shown that $\mathrm{Ph}_{3} \mathrm{P}=\mathrm{NPh}$ forms stable mercury and gold derivatives with metallation at an ortho-carbon atom of a P-bonded phenyl group via a lithiated intermediate. The gold compound forms a strong secondary interaction with the nitrogen 
atom, but there is only a weak one for the mercury example. The mercury compound should find extensive use in preparing cyclometallated complexes of other metals by transmetallation, while the gold complex would be a good precursor for an extensive range of new derivatives by ligand exchange reactions with the labile $\mathrm{Cl}$ groups. The compounds reported here using $\mathrm{Ph}_{3} \mathrm{P}=\mathrm{NPh}$ can be regarded as the prototypes for an extensive series given the ease with which the substituents on the $\mathrm{P}$ and $\mathrm{N}$ atoms can be varied to tune the steric, electronic and physical properties of the ligand.

\section{Supplementary material.}

Crystallographic data for the structural analyses have been deposited with the Cambridge Crystallographic Data Centre, CCDC no 293123 and 293124. Copies of this information may be obtained free of charge from the Director, CCDC, 12 Union Rd., Cambridge CB2 1EZ, UK (Fax: +44-1223-336033; e-mail: deposit@ccdc.cam.ac.uk or www: http://www.ccdc.cam.ac.uk).

\section{Acknowledgements}

We thank Dr Tania Groutso, University of Auckland, for collection of X-ray intensity data.

\section{References.}

1. A. W. Johnson, Ylides and Imines of Phosphorus, Wiley, New York, 1993.

2. H. Staudinger and J. Meyer, Helv. Chim. Acta, 2 (1919) 635; Y. G. Gololobov and L. F. Kasukhin, Tetrahedron, 37 (1981) 437. 
3. A. V. Kirsanov, Isv. Akad. Nauk SSSR (1950) 426 [Chem. Abstr 45 (1951) 1503]; L. Horner and H. Oedinger, Liebigs Ann. Chem., 627 (1959) 142;

4. H. Alper, J. Organometal. Chem., 127 (1977) 385.

5. J. Vicente, J. A. Abad, R. Clemente, J. Lopez-Serrano, M. C. Ramirez de Arellano, P. G. Jones and D. Bautista, Organometallics, 22 (2003) 4248.

6. M. A. Leeson, B. K. Nicholson and M. R. Olsen, J. Organometal. Chem., 579 (1999) 243.

7. P. Wei, K. T. K. Chan, D. W. Stephan, Dalton Trans., (2003) 3804; K. T. K. Chan, L. P. Spencer, J. D. Masuda, J. S. J. McCahill, P. Wei and D. W. Stephan, Organometallics, 23 (2004) 381.

8. S. Wingerter, H. Gornitzka, G. Bertrand and D. Stalke, Eur. J. Inorg. Chem., (1999) 173; S. Wingerter, H. Gornitzka, R.Bertermann, S. K. Pandey, J. Rocha and D. Stalke, Organometallics, 19 (2000) 3890.

9. W. Henderson, Adv. Organometal. Chem., accepted, 2006; M. B. Dinger, W. Henderson, J. Organometal. Chem., 560 (1998) 233; W. Henderson, B. K. Nicholson, S. J. Faville, D. Fan, J. D. Ranford, J. Organometal. Chem., 631 (2001) 41 .

10. M. B. Dinger, W. Henderson, J. Organometal. Chem., 557 (1998) 231; M. B. Dinger, W. Henderson, J. Organometal. Chem., 577 (1999) 219; W. Henderson, B. K. Nicholson and A. G. Oliver, J. Organometal. Chem., 620 (2001) 182.

11. M. A. Cinellu, A. Zucca, S. Stoccoro, G. Minghetti, M. Manassero and M. Sansoni, J. Chem. Soc., Dalton Trans., (1995) 2865; Y. Fuchita, H. Ieda, A. 
Kayama, J. Kinoshita-Nagaoka, H. Kawano, S. Kameda and M. Mikuriya, J. Chem. Soc., Dalton Trans., (1998) 4095.

12. W. Henderson, B. K. Nicholson and A. W. Wilkins, J. Organometal. Chem., 690 (2005) 4971.

13. R. V. Parish, Metal Based Drugs, 6 (1999) 271; R. V. Parish, B. P. Howe, J. P. Wright, J. Mack, R. G. Pritchard, R. G. Buckley, A. M. Elsome and S. P. Fricker, Inorg. Chem., 35 (1996) 1659; R. G. Buckley, A. M. Elsome, S. P. Fricker, G. R. Henderson, B. R. C. Theobald, R. V. Parish, B. P. Howe and L. R. Kelland, J. Med. Chem., 39 (1996) 5208; U. Abram, K. Ortner, R. Gust, K. Sommer, J. Chem. Soc., Dalton Trans., (2000) 5208; K. Palanichamy and A. C. Ontko, Inorg. Chim. Acta, 359 (2006) 44. See also E. R. T. Tiekink, Crit. Rev. Oncol. Hematol. 42 (2002) 225;

14. P. A. Bonnardel, R. V. Parish and R. G. Pritchard, J. Chem. Soc., Dalton Trans., (1996) 3185; R. V. Parish, J. P. Wright and R. G. Pritchard, J. Organometal. Chem., 596 (2000) 165; J. Vicente, M. T. Chicote and M. D. Bermúdez, Inorg. Chim. Acta, 63 (1982) 35; J. Vicente, M. T. Chicote and M. D. Bermúdez, J. Organometal. Chem., 268 (1984) 191; J. Vicente, M. D. Bermúdez, F. J. Carrión and P. G. Jones, Chem Ber., 129 (1996) 1301.

15. W. Henderson, B. K. Nicholson and L. J. McCaffrey, Polyhedron, 17 (1998) 4291.

16. L. J. Arnold, J. Chem. Educ., 69 (1992) 811.

17. W. Wiegraebe and H. Bock, Chem. Ber. 101 (1968) 1414.

18. R. H. Blessing, Acta Cryst., A51, (1995) 33. 
19. G. M. Sheldrick, SHELX97 Programs for the solution and refinement of crystal structures, University of Göttingen, Germany, 1997.

20. L. J. Farrugia, WinGX, Version 1.70.01, University of Glasgow, UK; L. J.

Farrugia, J. Appl. Cryst., 32 (1999) 837.

21. C. G. Stuckwisch, J. Org. Chem., 41 (1976) 1173.

22. P. E. Garrou, Chem. Rev., 81 (1981) 229.

23. T. P. Braun, P. A. Gutsch, H. Zimmer, Z. Naturforsch., B54 (1999) 858.

24. E. Bohm, K. Dehnicke, J. Beck, W. Hiller, J. Strahle, A. Maurer and D. Fenske, Z. Naturforsch., B43 (1988) 138. 
Table 1

Structural Parameters for the orthomercurated compound $\mathbf{3}$ and the cycloaurated compound $\mathbf{4}$.

Bond lengths $(\AA)$

$\begin{array}{lll} & 3, \mathrm{M}=\mathrm{Hg} & \mathbf{4}, \mathrm{M}=\mathrm{Au} \\ \mathrm{M}-\mathrm{C}(12) & 2.066(3) & 2.035(5) \\ \mathrm{M}-\mathrm{N}(1) & 2.637(2) & 2.034(4) \\ \mathrm{M}-\mathrm{Cl}(1) & 2.3303(7) & 2.368(1) \\ \mathrm{M}-\mathrm{Cl}(2) & - & 2.289(1) \\ \mathrm{P}(1)-\mathrm{N}(1) & 1.589(2) & 1.618(4) \\ \mathrm{P}(1)-\mathrm{C}(11) & 1.814(3) & 1.790(5) \\ \mathrm{N}(1)-\mathrm{C}(41) & 1.409(4) & 1.433(6) \\ \mathrm{C}(11)-\mathrm{C}(12) & 1.396(4) & 1.403(6)\end{array}$

Bond Angles (degrees)

$\begin{array}{lll} & \mathbf{3}, \mathrm{M}=\mathrm{Hg} & \mathbf{4}, \mathrm{M}=\mathrm{Au} \\ \mathrm{N}(1)-\mathrm{M}(1)-\mathrm{C}(12) & 80.07(9) & 84.86(17) \\ \mathrm{C}(12)-\mathrm{M}-\mathrm{Cl}(1) & 170.16(8) & 174.9(1) \\ \mathrm{Cl}(1)-\mathrm{M}-\mathrm{Cl}(2) & - & 90.70(4) \\ \mathrm{M}(1)-\mathrm{N}(1)-\mathrm{P}(1) & 106.7(1) & 113.2(2) \\ \mathrm{P}(1)-\mathrm{N}(1)-\mathrm{C}(41) & 126.4(2) & 123.2(3) \\ \mathrm{N}(1)-\mathrm{P}(1)-\mathrm{C}(11) & 106.8(1) & 101.3(2)\end{array}$


Captions to figures.

Figure 1. The structure of the orthomercurated complex $\mathbf{3}$

Figure 2. The structure of the cycloaurated complex 4 . 


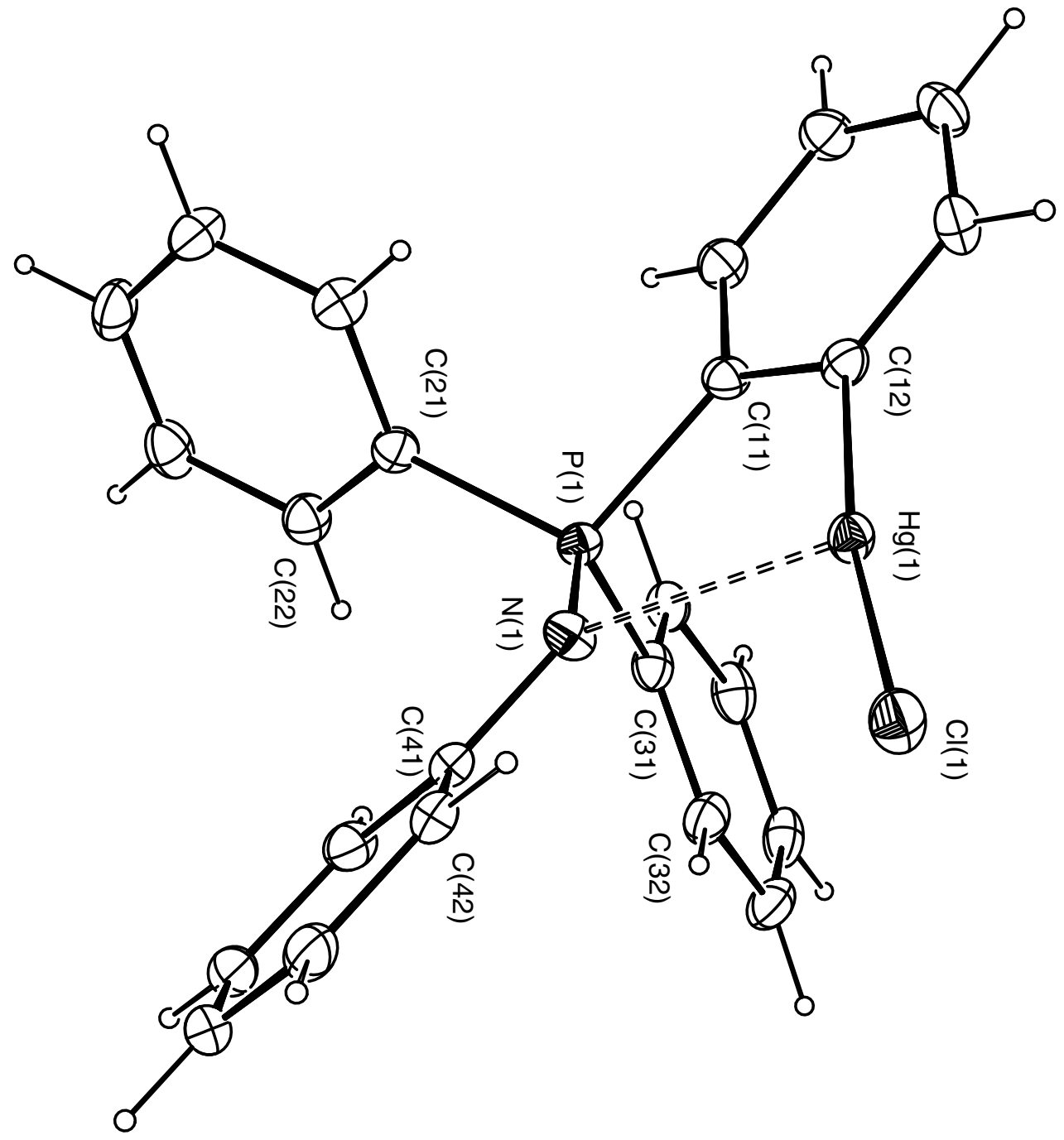

Figure 1 


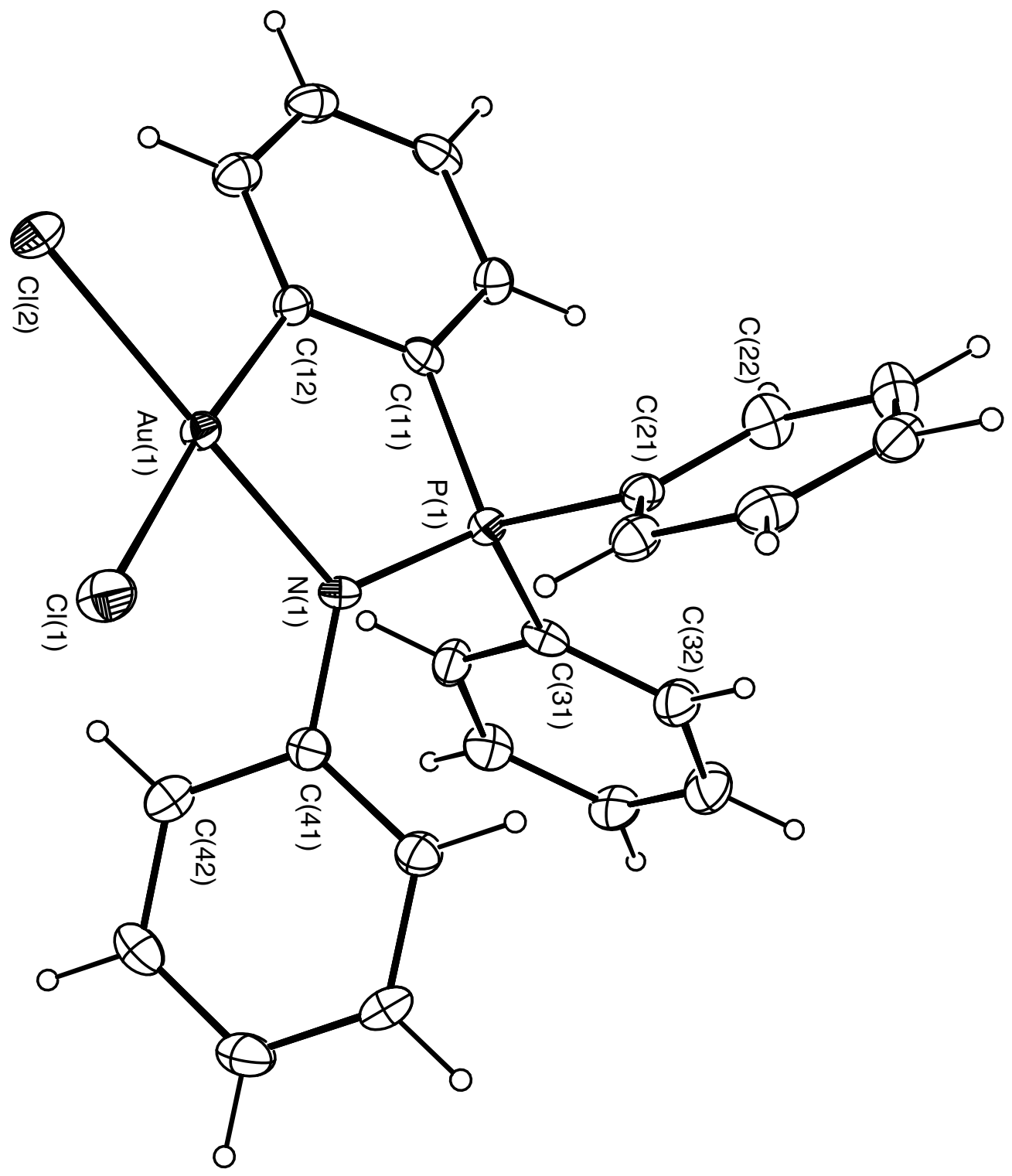

Figure 2 